\title{
Experimental Analysis of Cooling Performance of Spraying Water Automatically on the Galvanized Zinc- Roofs
}

\author{
Jefrey. I. Kindangen ${ }^{\# 1}$, Linda Tondobala ${ }^{\# 2}$, Markus K. Umboh ${ }^{* 3}$ \\ \# Architectural Engineering Department, Sam Ratulangi University \\ Jl. Kampus Unsrat Manado 95115, Indonesia \\ ${ }^{1}$ jkindangen@unsrat.ac.id \\ 2lindtmt@yahoo.com \\ * Mechanical Engineering Department, Sam Ratulangi University \\ Jl. Kampus Unsrat Manado 95115, Indonesia \\ 33arkus_umboh@yahoo.com
}

\begin{abstract}
In the North Sulawesi Province in Indonesia, more than $\mathbf{9 0 \%}$ of buildings use corrugated galvanized zinc roofing. A zinc roof may cause overheating in the room if no proper treatment is implemented according to the thermal properties of the material. This study aims to find out the cooling of galvanized zinc-roofs by using an automatic water spraying to lower indoor air temperatures in buildings in humid tropical climates. Spraying water onto the roof surface is performed on the test cell and it can reduce the average roof surface temperature by up to $5{ }^{\circ} \mathrm{C}$, but water should be sprayed about 10-15 minutes continuously. Automatic water spraying can control indoor temperatures below the exterior temperature, but still cannot reach the comfort temperature especially during the day. By spraying it is advantageous to lower the temperature to about $1.55{ }^{\circ} \mathrm{C}$ less than the comfort temperature than without spraying. Further research is needed, primarily to conserve the used water by reusing it and also cooling it again.
\end{abstract}

Keyword - automation, hot and humid climate, passive cooling, roofs, water spraying

\section{INTRODUCTION}

There are several types of roofs for houses and buildings, such as concrete roofs, clay tiles, shingles and asbestos roofs, zinc roofs and roofs of fibres and coconut leaves, which is often found in North Sulawesi in Indonesia. Concrete roofing has the advantage of being used for some activities, such as the creation of a clove drying area used for casual seating and parties. This type of roof has the issue of possible seepage. The roof tiling requires stronger and larger roof construction, which will be certainly more expensive because of the weight of the tile itself. Roof tiles have the advantage of acting as the high heat capacity material that can delay or make slower the propagation of heat to the room in the building. The roof made of shingles and asbestos are rarely used due to the limited production of this type of roof. People still use fibres and leaves of palm trees as roofing materials for buildings that are simple and not permanent. Although this type of roof is very good at reducing heat propagation into the building and is suitable for the humid tropical climate, it is flammable and production is limited. Therefore, it can only be applied to relatively simple buildings and certain types of construction. Galvanized zinc is widely used as roofing materials. This is because the roof structure is very simple, inexpensive and very easily obtainable on the market. The use of galvanized zinc material as roof covers is very popular in Indonesia. According to the data from the Bureau of Statistics of the North Sulawesi Province [1], 92.41\% of houses use galvanized zinc roofs, as described in TABLEI.

TABLE I. Types of roof materials in North Sulawesi Province, Indonesia

\begin{tabular}{|c|c|}
\hline Types of roofing & Percentage of houses (\%) \\
\hline Concrete roofing & 1.85 \\
\hline Clay Tile roofing & 1.00 \\
\hline Shingle roofing & 2.21 \\
\hline Galvanized zinc roof & 92.41 \\
\hline Asbestos roofing & 0.41 \\
\hline Roof of palm fibres & 2.10 \\
\hline Others & 0.02 \\
\hline
\end{tabular}


Almost the majority of houses and buildings have galvanized zinc roofs. The use of zinc is very popular because it is very practical to use and construct as well as being widely available in the public market. Another reason is the socio-cultural aspect of the local community. There is a cultural perception that triggers the widespread use of zinc as a roof. One of the causes is the earthquake disaster experienced by residents in North Sulawesi, Ambon and surrounding areas in 1898, when a large earthquake caused many buildings, especially those that use heavy roofs such as clay or ceramics, to become damaged and destroyed. Thus, the consideration and decision not to use heavy roofing materials is always in their concern. This is the main reason why most houses in North Sulawesi Province, especially in Manado use corrugated zinc as a lightweight roofing material, as shown in Fig. 1.

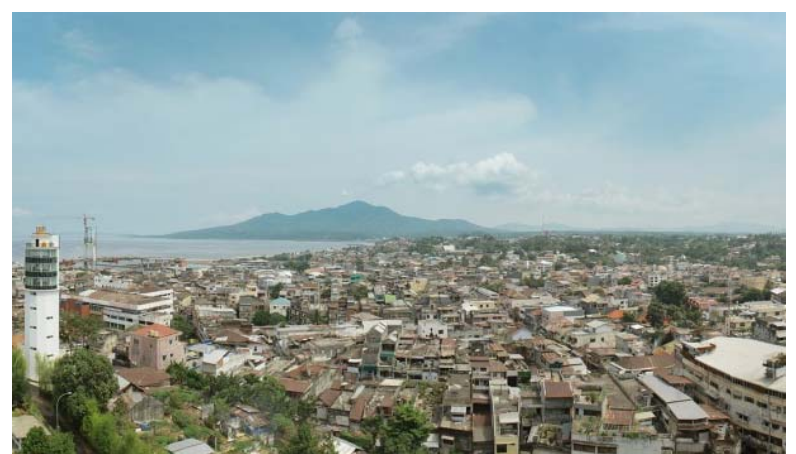

(a)

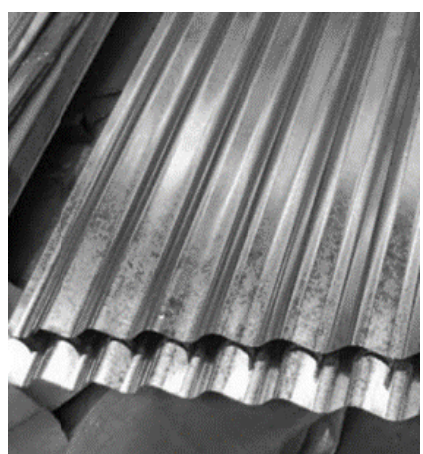

(b)

Fig. 1. (a) Roofs of Manado [2]; and (b) an example of corrugated zinc roof sheet used widely in the region

Despite its advantages, its application can cause overheating without proper treatment due to the thermal properties of the material. Zinc is a type of metal that generally has high electrical conductivity, high thermal conductivity and high density. Due to the high thermal conductivity properties, heat transfer across the material occurs at a faster rate than all materials with low thermal conductivity. Thermal conductivity occurs in temperature-dependent materials. In general, the material becomes more conductive to heat when the average temperature increases. The thermal conductivity of zinc is $112.2 \mathrm{~W} / \mathrm{m}-{ }^{\circ} \mathrm{C}$. Many homes that use galvanized zinc do not use an insulating layer under the roof because it will increase the cost of construction becomes more expensive. Taking into account the nature of the zinc material, its use in constructing the roof of a building must be done with care and with certain treatment. As a roof cover, this material easily becomes hot and will release heat to the surrounding room. If it is not hindered or even cooled, it can cause the room under it to become hotter. This is the reason that drives our study, which aims to cool the uninsulated zinc roof in an indirect evaporative way by spraying water.

Concerning the energy conservation, passive cooling is one of the strategies needed for humid tropical climate conditions. Indeed, there are some passive cooling schemes that can be utilized for buildings in hot and humid climates in this case, such as natural ventilation, radiant cooling, indirect evaporative cooling and the soil as a cooling source. At this time, natural ventilation was applied exclusively. Several studies conducted by some scientist (Haasea and Amatob [3]; Kindangen [4][5]; Tantasavasdi et al. [6]; Wang and Wong [7][8]) have investigated of the potential of natural ventilation to achieve thermal comfort in warm and humid climates. In general, they concluded that it was important for improving the performance of natural ventilation, which can decrease indoor air temperatures by about $2-4{ }^{\circ} \mathrm{C}$. In addition to natural ventilation, there are still other techniques included in the passive cooling strategy. Although some passive cooling strategies may be used, only a few are suitable for buildings in humid tropical climates. One of them is an indirect evaporative cooling that will be investigated in this paper.

The evaporative cooling consists of two main ways: direct and indirect. Regarding its climatic applicability, the direct evaporative cooling can be an inexpensive system in desert regions with too low humidity that is desirable physiologically as well. However, in more humid region, the efficiency of the system has reduced and the higher humidity may be undesirable from the comfort aspect. Indirect evaporative cooling would then be an appropriate solution as described by Givoni [9]. An indirect evaporative cooling is one of the most overlooked passive cooling strategies in the humid tropics. This scheme can lower indoor air and radiant temperature without elevating the indoor vapor content. The maximum wet bulb temperature (WBT) for application of indirect evaporative cooling is $25^{\circ} \mathrm{C}$ and the maximum dry bulb temperature (DBT) is $46{ }^{\circ} \mathrm{C}$, where this range is very appropriate to the conditions in the region. 
The use of an evaporative roof cooling system is not a new idea as this has been studied since the beginning of 1939. Furthermore, due to the recent energy crisis, the method of roof spray cooling became more widely acceptable and desirable [10]. The operation of roof spray cooling is very simple and basic as the basic concept is to wet the hot surfaces and cool them with water. The main purpose is to stop the heat from entering the room and reduce the cooling costs in the building.

Some scientists have tried to discover the mechanisms of indirect evaporative cooling strategies and applications. Among others, Givoni [11] and Joudi and Mehdi [12] examined indirect evaporative cooling with varying cooling loads for housing. They concluded that passive cooling systems can reduce room temperature, but these systems would differ from one another depending on different climates. The study of Kim et al. [13] has provided practical insight on how the evaporative cooling-based $100 \%$ outdoor air system operates and how each essential component, such as the indirect evaporative cooler, cooling coil, direct evaporative cooler, heating coil and sensible heat exchanger, should be controlled during the seasons for realizing energy conservation benefits.

Wongsuwan et al. [14] have conducted an experimental study on the roof pond house under tropical climatic conditions and they concluded that the system could reduce the indoor temperature by $2-4{ }^{\circ} \mathrm{C}$ compared to the outdoor temperature. These results are similar with Givoni [9], he found that with the pond roof the total difference in heat exchange between the ceiling and the indoor space is also maximized, enabling satisfactory cooling even with a small temperature difference of about $2-3{ }^{\circ} \mathrm{C}$ between the ceiling and the space below it.

As reported by Spanaki [14], Jain and Rao [15] have experimentally investigated in some detail the effect of roof pond and roof spray at the ceiling surface of a thick reinforced concrete roof exposed to a hot-day sunny climate in detail. It was seen that the peak roof temperature decreased from $55^{\circ} \mathrm{C}$ to $28{ }^{\circ} \mathrm{C}$ with the roof spray as compared to a reduction from $55^{\circ} \mathrm{C}$ to $32{ }^{\circ} \mathrm{C}$ in the case of the roof pond. The condition was obviously due to more efficient evaporation of water at the ceiling surface. The roof surface temperature was observed to undergo a drop of $15^{\circ} \mathrm{C}$ as compared to $13^{\circ} \mathrm{C}$ in the case of the water pond.

Spanaki [14] had reviewed the literature of some studies on the different type of roof ponds for cooling purposes and reported that the spraying system is usually preferred for larger cooling loads. The usefulness of the roof spray-cooling was found to be most useful in buildings with lightly constructed, poorly insulated roofs. He has also reported that the research by using numerical computation for the heat flux carried out for the New Delhi's climate gave the results that water-sprayed system could reduce in the maximum heat flux entering the room of $41 \%$ corresponding to $35 \%$ of reduction in daily heat input into the room. He argued that research conducted by another researcher in the same climate found that maximum cooling was achieved by spraying water on the roof. This is consistent with the research of Zhou et al. [17], who studied the effect of the difference between a grass roof and the roof by spraying water in a building with reinforced concrete (RC) construction. The conclusion is that the roof by spraying water is not suitable for an RC building with a high level of insulation in the ceiling.

Teixera and Labaki [18] have also carried out a study of evaporative cooling in a tropical climate by using the cell tests with fibre-cement roofing without concrete slabs. They concluded that the technique of roof spraying can be satisfied if only the surface internal temperature attenuation is considered for the hottest months in the region. Compared to the water spray system, the roof pond requires more expensive and large construction, especially considering waterproofing. Another limitation of the roof pond system is the need to have a flat roof capable of supporting a load of about $300 \mathrm{~kg} / \mathrm{m}^{2}$ and limited form of architectural design [9].

With regard to thermal comfort analysis, Karyono et al. [19] reported that the new adaptive American Society of Heating, Refrigerating and Air-Conditioning Engineers (ASHRAE) thermal comfort standard show that comfort temperatures tend to have a correlation with the average monthly temperature at any given location. They proposed a neutral temperature of $26.4^{\circ} \mathrm{C}$ and the range comfort temperature of 24.9 to $28.0^{\circ} \mathrm{C}$ in terms of air temperature and it is very different to the current standard for thermal comfort based on ASHRAE 55 1992 which recommended a neutral temperature of $24.0^{\circ} \mathrm{C}$ with the range of comfort between 22 and $26^{\circ} \mathrm{C}$ of air temperature. Their proposal is suitable for Indonesia's climate. Some studies showed that there is a correlation between comfort temperature and the mean outdoor temperature. One of them, Humphreys [20] proposed a linear relationship between comfort temperature and mean outdoor temperature for naturally ventilated buildings as:

$$
\mathrm{T}_{\mathrm{c}}=0.534 \mathrm{~T}_{\mathrm{o}}+12.9
$$

Where $T_{c}$ is the comfort temperature and $T_{0}$ is the mean outdoor temperature.

This formula is used to analyze the achievement of thermal comfort in the building due to the use of galvanized zinc. Similarly, the proposed temperature range and the neutral temperature will be used to analyze thermal comfort in the next section. 


\section{Methodology}

The study was conducted in Manado located in Indonesia's North Sulawesi province, at a latitude of $1.4583^{\circ} \mathrm{N}$ and a longitude of $124.8260^{\circ} \mathrm{E}$. As part of the humid tropics, Manado has the hottest month in October with an average temperature of $29.10{ }^{\circ} \mathrm{C}$ and the coldest in January with an average temperature of $26.90^{\circ} \mathrm{C}$. In general, the temperature difference between the hottest and coldest months is not too large. The rainy period occurs during November-March, with the largest average rainfall occurring in January (465 mm). The amplitude of daily and monthly temperatures in a year is small. The average high relative humidity ranges from 64\% in October and 81\% in January and March, as shown in Fig. 2.

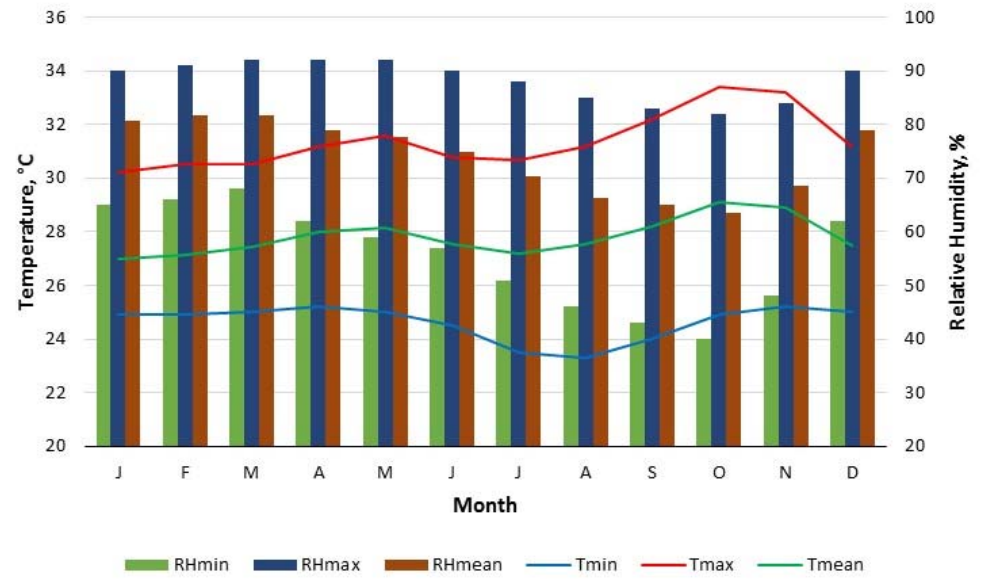

Fig. 2. Climatic data for North Sulawesi Province, Indonesia

A test cell has been built with a length of $1.50 \mathrm{~m}$, a width of $1.50 \mathrm{~m}$ and a height of $2.50 \mathrm{~m}$. The walls are made of plywood and the roof is made of corrugated galvanized zinc with a surface area of $3.80 \mathrm{~m}^{2}$. In regard to eliminate the influence of the soil moisture, the plywood floor is raised about $80 \mathrm{~cm}$ from the ground. This is similar to the house on stilts made of wooden boards that are widely traded and built in this region. For investigating the effect of water spraying, this cell has no ceiling and no attic ventilation, and the roof is tilted in one direction only. This test cell has two windows measuring $30 \times 40 \mathrm{~cm}$, which is located on the right and left sides (North and South) for avoiding the direct sunlight that could penetrate through windows. The test model is placed outside the house so that it can be exposed to direct sunlight as effectively as possible during the morning - evening, as illustrated in Fig.3.

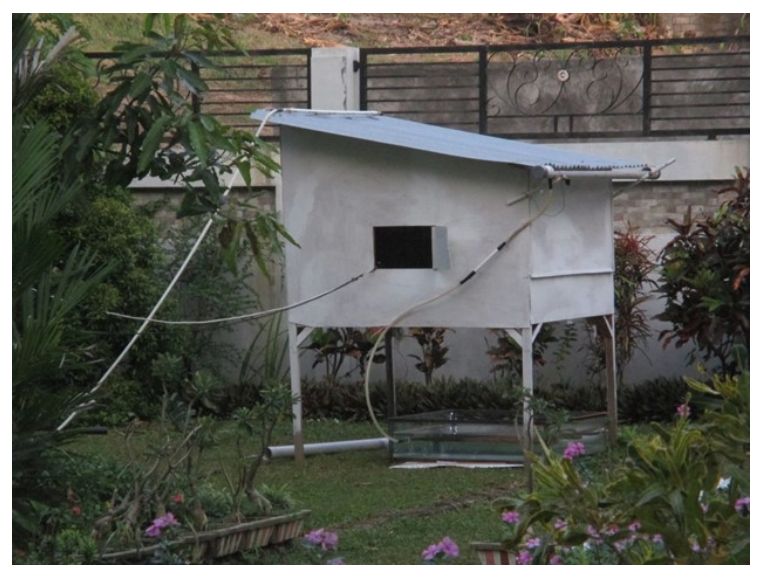

(a)

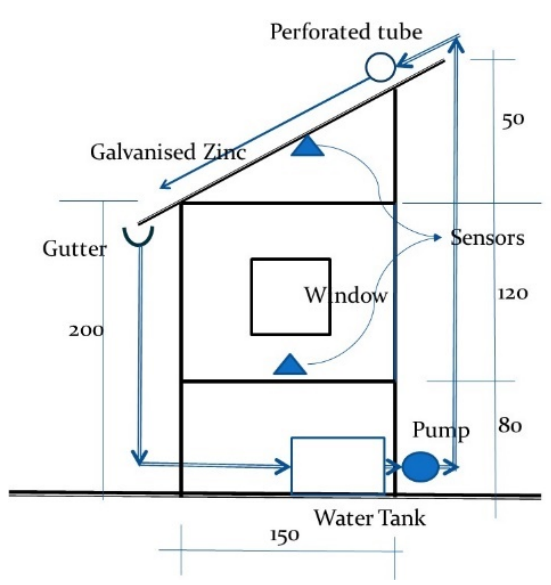

(b)

Fig. 3. (a) The test cell is placed outside the room and equipped with automatic water spraying and (b) A schematic section of the test cell 


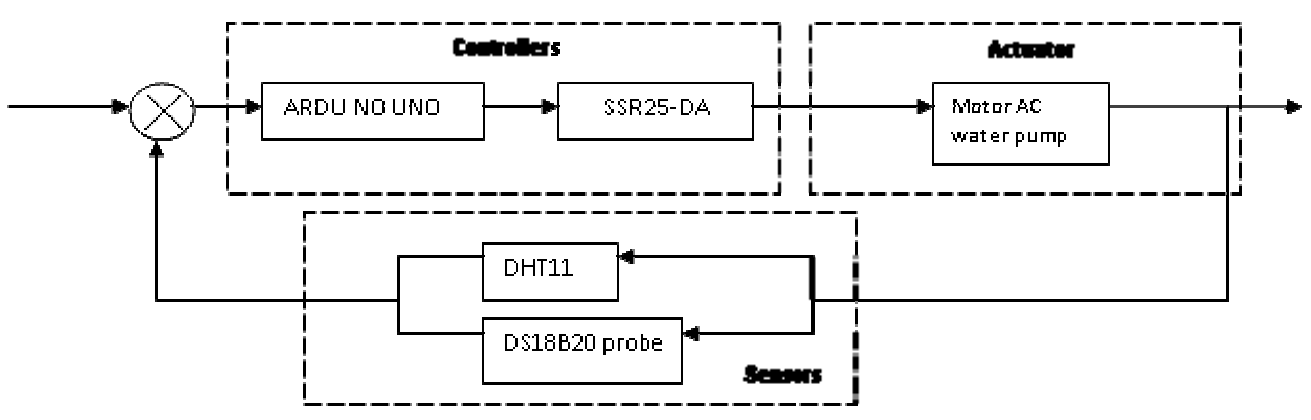

Fig. 4. A block diagram of automatic water spraying device

The automatic roof spraying device is designed and installed by applying a subsystem consisting of sensors, controllers and actuators as illustrated with a block diagram in Fig. 4. The one wire digital temperature sensor DS18B20 is used to detect the roof surface temperature and attached under the roof, while the DHT11 digital temperature and humidity sensor is used to measure indoor air temperature and humidity and placed in the middle of the room. These sensors are very easy and suitable to use with the Arduino microcontroller and the Solid State Relay (SSR) 25-DA, having very precise stability and calibration levels.

The device is set to work when the roof temperature reaches a certain degree as a boundary parameter; for this purpose, the first attempt is set at $31{ }^{\circ} \mathrm{C}$ and final set at $38{ }^{\circ} \mathrm{C}$ as described in a flow chart of an actuator activation in Fig.5a. If it reaches or even exceeds that limit, the controller will turn on the actuator and the pump will spray water onto the roof surface, as in Fig.5b. However, if the roof surface temperature drops to the threshold value, the controller will turn off the actuator and the pump will not work anymore. The measurement results for both roof surface temperature and room temperature can be read on a LCD monitor as presented in Fig.5c.

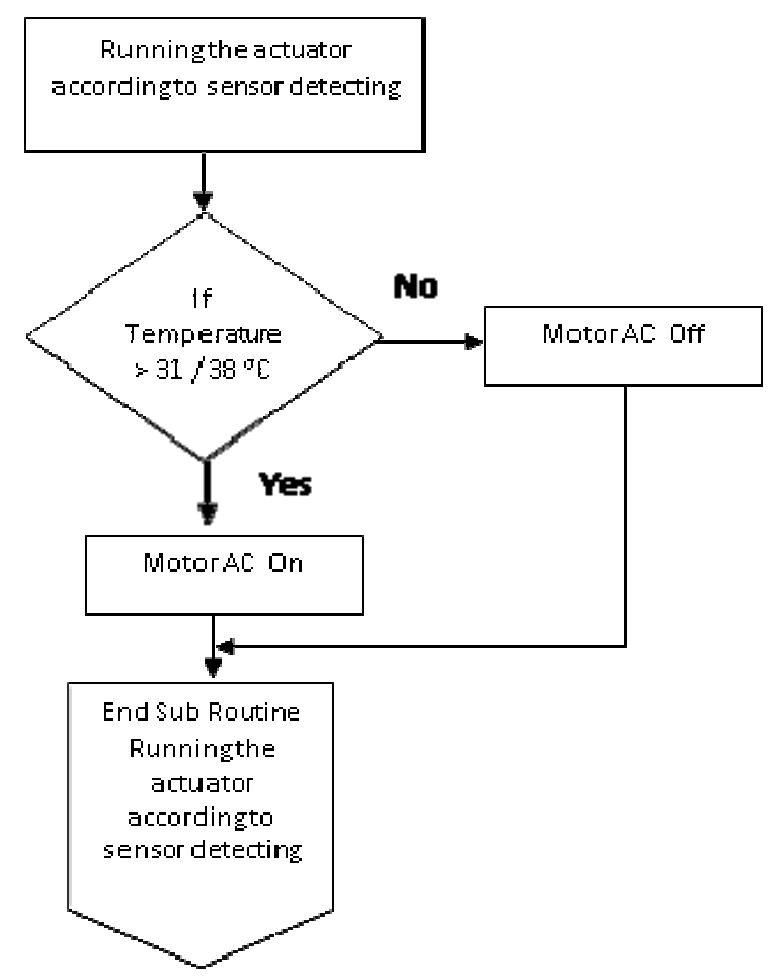

(a)

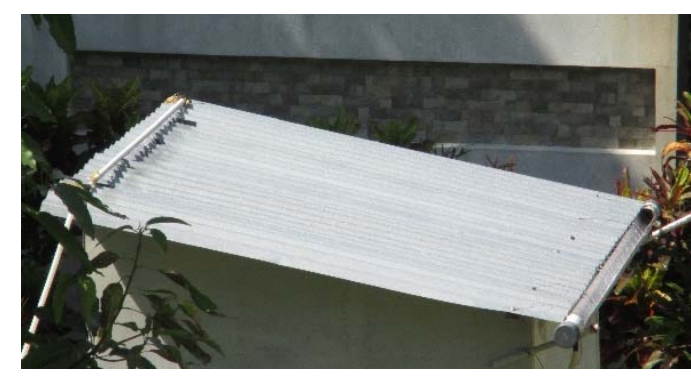

(b)

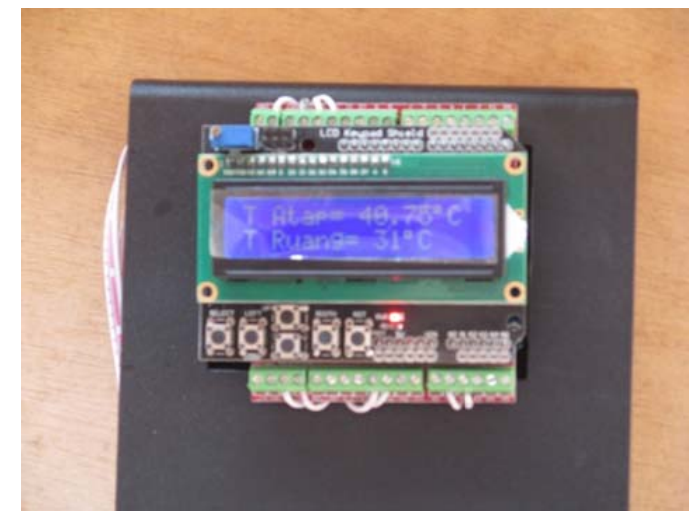

(c)

Fig. 5. (a) A flow chart of an actuator activation; (b) Water is spraying onto the surface; (c) Detection of sensors displayed at LCD monitor

The water spray is installed by a closed circuit connected to a submersible pump with a capacity of $4000 \mathrm{l} / \mathrm{h}$ and $100 \mathrm{~W}$ power, and a hollow polyvinyl chloride (PVC) tube placed at the highest edge of the roof. The PVC pipe is perforated every $2.50 \mathrm{~cm}$ to form a straight line. These holes are used to spray water on the entire surface of the roof when the pump is turned on. The relative humidity and temperatures of the interior, the exterior and surface of the roof are measured using three RC-4HC temperature and humidity data loggers, which record every 30 minutes to obtain sufficient analytical data. 


\section{III.RESULTS AND DISCUSSION}

Measurements were made in March and September, this corresponds to the beginning of the dry season. By reason of the monthly temperature amplitudes in a year is modest; then it can be deduced that it is reasonable to do the measurements in March. By applying equation(1), it found that the early March until the beginning of June and in August until November the mean outdoor temperatures are above of the comfort temperature as shown in Fig.6. It means that more efforts are needed for cooling indoor air temperature in the months of March - June and August - November for achieving the comfort temperature.

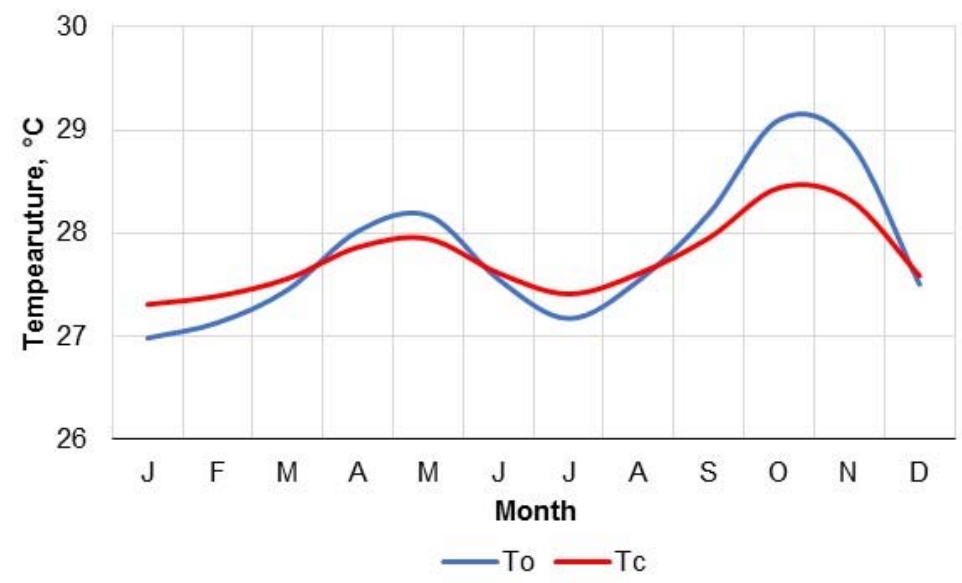

Fig. 6. The mean outdoor temperatures $\left(T_{0}\right)$ vs. comfort temperature $\left(T_{c}\right)$ for naturally ventilated building

Measurements were made on the test cell to obtain zinc roof surface temperature data and interior temperature, including exterior temperatures performed without any treatment (i.e., without spraying water to the roof). The average indoor temperature is above the exterior temperature between 7:00 a.m. and 2:00 p.m.; at that time, roof surface temperatures reached a maximum value of $61{ }^{\circ} \mathrm{C}$ during the day. Toward the afternoon (3:00 p.m. to 6:00 a.m.) and early morning, the room temperature is below the exterior temperature.

The evaluation of the effect of spraying water on the surface of the zinc roof was initially done manually. It is noted that there was a decrease in zinc surface temperature of $4-5{ }^{\circ} \mathrm{C}$. The zinc surface temperature increases slowly after about 5 minutes of previous spraying. This measurement is performed in late March when the window on the test cell is opened and the indoor wind speed is measured at $0.8 \mathrm{~m} / \mathrm{s}$. The same is done repeatedly during the time interval of 11:00 a.m.-3:00 p.m., note that there is also the same thing that decreases the roof temperature $4-5{ }^{\circ} \mathrm{C}$ due to water spraying, as described in TABLE II. This reduction is typical for daytime conditions. However, manual spraying becomes impractical as it should be repeated without knowing when spraying should be done.

TABLE II. Results of measurements before and after spraying water manually

\begin{tabular}{|c|c|c|c|}
\hline No. & Measurements & Before spraying & After spraying \\
\hline 1 & Temperature of zinc surface & $41.80^{\circ} \mathrm{C}$ & $37.70^{\circ} \mathrm{C}$ \\
\hline 2 & Average indoor temperature & $35.60^{\circ} \mathrm{C}$ & $35.40^{\circ} \mathrm{C}$ \\
\hline 3 & Indoor relative humidity & $40.00 \%$ & $39.50 \%$ \\
\hline
\end{tabular}

The metal cooling process due to its high thermal conductivity shall be carried out continuously. Spraying with water can quickly lower the metal surface temperature, but the temperature will rapidly increase after spraying. From the results of this study, it is noted that roof surface temperatures increase gradually after 5-10 minutes.

Without water spraying, roof surface temperatures begin to rise dramatically at 9:00 a.m. and fluctuate until 1:00 p.m., with a maximum temperature of $57^{\circ} \mathrm{C}$. In the morning until noon (7:00 a.m. to 2:00 p.m.), the temperature of the indoor air is higher than the exterior air by an average of $0.63{ }^{\circ} \mathrm{C}$. This phenomenon is caused by the properties of metals, such as zinc, due to heat being more easily absorbed and radiated. This is the reason why the attempt to lower the roof surface temperature does not significantly affect the interior temperature and even, the roof surface temperature will eventually become hotter. After 3:00 p.m., the indoor air temperature drops to be cooler than the outside. 
Automatic water spraying applications on cell tests can be easier and more controlled when spraying should be done. The roof surface temperature limit is initially set at $31^{\circ} \mathrm{C}$, which means the device will work when the roof temperature reaches $>31{ }^{\circ} \mathrm{C}$. Automatic spraying of water can significantly reduce the roof surface temperature between $38-51{ }^{\circ} \mathrm{C}$. In this test it is found that spraying water is no longer able to lower roof temperatures by less than $30^{\circ} \mathrm{C}$, although spraying continued. The test is performed to obtain an appropriate temperature threshold. After several experiments, it was found that the temperature limit was at $37.8{ }^{\circ} \mathrm{C}$. Therefore, it is necessary to re-program the algorithms programming of device with modifying the roof surface temperature threshold to be $38{ }^{\circ} \mathrm{C}$. Moreover, the temperature parameter is adjusted to $38{ }^{\circ} \mathrm{C}$, which means the motor will turn when the roof temperature reaches $38^{\circ} \mathrm{C}$ and water will be sprayed.

For comparing the effects of water spraying, it is necessary to separate this experiment into two conditions, namely with water spraying and no spraying. The roof surface, interior and exterior temperatures without water spraying are shown in Fig. 7a. Fig. 7b shows the effect of water spraying automatic to the roof surface. With automatic water spraying, the temperature is always maintained at less than $38{ }^{\circ} \mathrm{C}$, and provides an effective daytime benefit when the indoor air temperature is lower than the exterior during the day. In fact, spraying water automatically onto a zinc roof surface can significantly reduce its surface temperature, which can be even by 14 ${ }^{\circ} \mathrm{C}$.

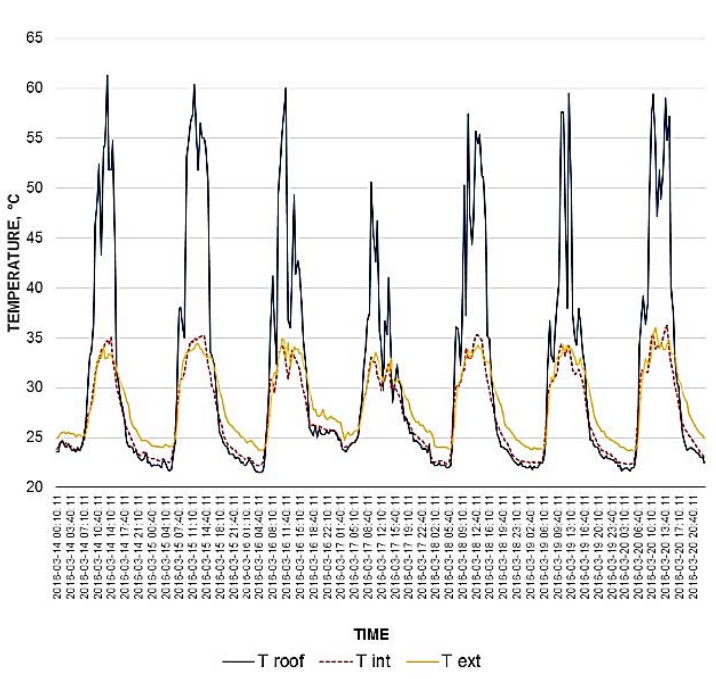

(a)

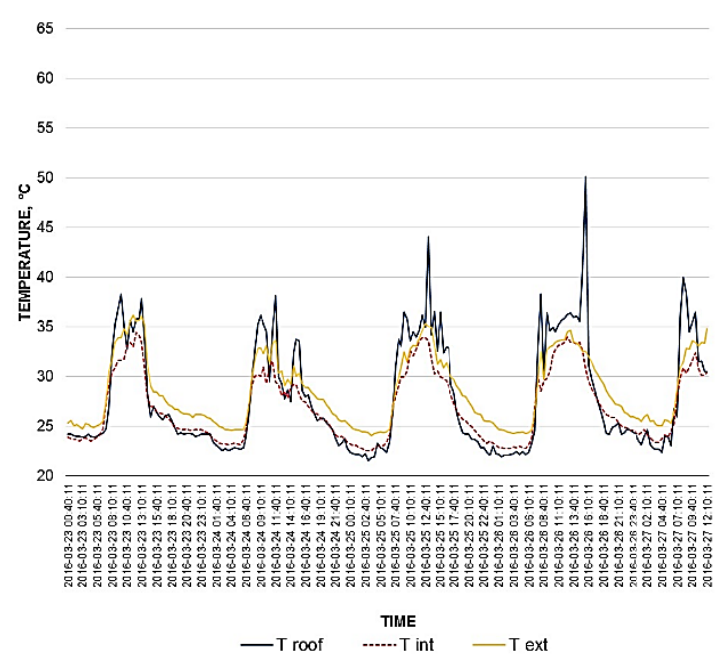

(b)

Fig. 7. Comparison of the roof surface $\left(\mathrm{T}_{\text {roof }}\right)$, interior $\left(\mathrm{T}_{\mathrm{int}}\right)$ and exterior $\left(\mathrm{T}_{\mathrm{ext}}\right)$ temperatures: (a) without spraying the roof; and (b) with spraying the roof

Compared with automatic water spraying onto the surface of the zinc roof, the temperature can be maintained to be less than $38^{\circ} \mathrm{C}$. If the temperature jumps drastically at 2:00 p.m., spraying water will decrease the roof surface temperature. The advantage is that indoor air temperatures can be controlled under the exterior air temperature for a full day. However, it is important to evaluate the effect of water spray on the roof surface in detail by determining the temperature difference between the interior temperature due to water spraying or nonspraying with the comfort temperature as a function of the average exterior temperature. For this purpose, the average temperature difference between the two conditions was noted when water spraying was performed, the difference was $1.55{ }^{\circ} \mathrm{C}$. In contrast, the difference was $2.12{ }^{\circ} \mathrm{C}$ without spraying, as shown in Fig. 8. This suggests that automatic spraying of water on zinc roofing surfaces provides more advantages for cooling interior spaces, even though they have not been able to reach thoroughly at comfort temperatures, especially in the middle of the day. Likewise, during the day, water spraying can not carry room temperature over a comfortable temperature range for the Indonesian climate, which is between 24.9 to $28^{\circ} \mathrm{C}$. Thus, other strategies are still needed to promote total interior temperature reduction. 


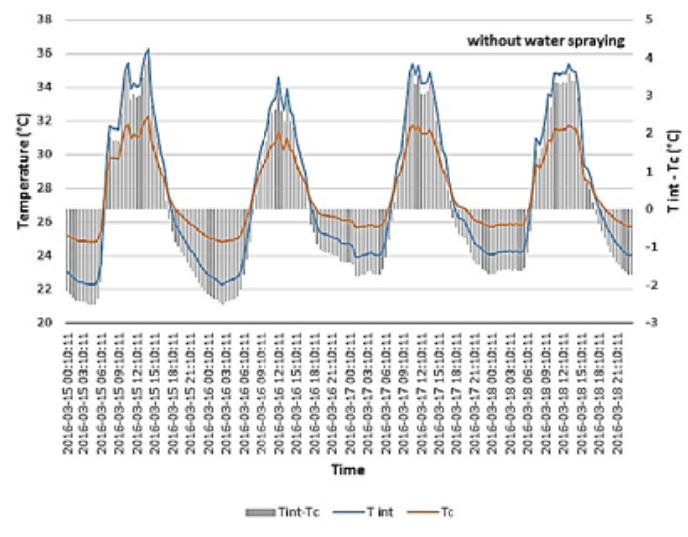

(a)

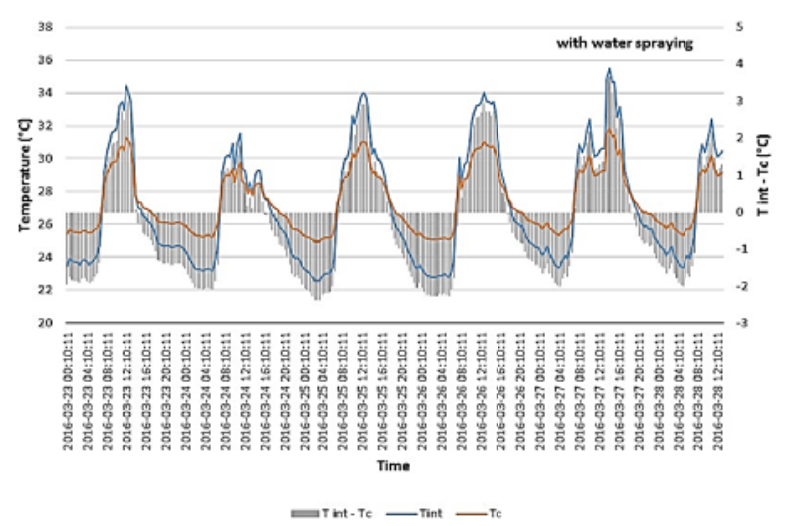

(b)

Fig. 8. The temperature difference between the comfort temperature $\left(T_{c}\right)$ and the indoor air temperature ( $\left.T_{\text {int }}\right)$ for: (a) without sprayingthe roof; and (b) with spraying the roof

\section{CONCLUSION}

Spraying water on the surface of the galvanized zinc roof has been implemented on a test cell and found that it can reduce the average temperature by $5{ }^{\circ} \mathrm{C}$. With regards to effectively lower the roof surface temperature, water spraying should be repeated every 10-15 minutes, especially when the exterior temperature is very high.

For more practical and effective water spraying has been applied automatically. This device can work effectively, the pump will spray water to the surface of the roof when the roof surface temperature reaches $38^{\circ} \mathrm{C}$ or more.

The advantage of this method is mainly to reduce roof surface temperature compared to indoor temperature, although at noon it has not been able to reach the comfortable temperatures. The temperature difference between interior temperature and comfort temperature due to water spraying is lower than without water spraying. That is watering the roof makes closer the room temperature to a more comfortable room condition.

It is important to note that enforcing the scheme uses a substantial quantity of water if the water is not recycled. Thus, future studies need to examine how to reuse the water that has been heated after spraying and how to cool it back in order to reuse it for more economic use.

\section{ACKNOWLEDGMENT}

This research has been supported by the Ministry of Research, Technology and Higher Education of the Republic of Indonesia under the research scheme of "Produk Terapan" for the year 2016-2017. We would like to thank to the Head of Research Centre of Sam Ratulangi University for facilitating the research.

\section{REFERENCES}

[1] North Sulawesi Province's Bureau of Statistics, North Sulawesi Province in Number in 2015, Manado

[2] Manado City in Panoramic, avalaible online: http://www.panoramio.com/photo/86607811 (accessed on 16/09/2017)

[3] Haasea, M and Amatob, A. An investigation of the potential for natural ventilation and building orientation to achieve thermal comfort in warm and humid climates, Solar Energy 83(3), 389-399, 2009, https://doi.org/10.1016/j.solener.2008.08.015

[4] Kindangen, J. Window and Roof Configurations for Comfort Ventilation, Building Research and Information 25 (4), 215-225, 1997,DOI http://dx.doi.org/10.1080/096132197370345

[5] Kindangen, J. Applicability of Design Elements and Passive Design for Comfort Ventilation, the 2nd International Networks for Tropical Architecture (iNTA) Conference, Yogyakarta, 3-5 April 2006

[6] Tantasavasdi, C., Srebric, J. and Chen, Q. Natural ventilation design for houses in Thailand, Energy and Buildings 33(8), 815-824, 2001, https://doi.org/10.1016/S0378-7788(01)00073-1

[7] Wang, L. and Wong, N.H. Applying Natural Ventilation for Thermal Comfort in Residential Buildings in Singapore, Architectural Science Review 50(3), 224-233,2007

[8] Wang, L. and Wong, N.H. The impacts of ventilation strategies and facade on indoor thermal environment for naturally ventilated residential buildings in Singapore, Building and Environment 42(12), 4006-4015, 2007, https://doi.org/10.1016/j.buildenv.2006.06.027

[9] Givoni, B. Passive and Low Energy Cooling of Buildings, New York: Van Nostrand Reinhold, 263p.1994

[10] Carraso, A., Pittard, R., Kondepudi, S.N. and Somasundaram, S. Evaluation of a direct evaporative roof-spray cooling system, in Proceedings of the 4th Symposium on Improving Building Systems in Hot and Humid Climates, Houston, Texas, September 15-16, 94-101, 1987

[11] Givoni, B. Indoor temperature reduction by passive cooling systems, Solar Energy 85 (8), 1692-1726, 2011, DOI https://doi.org/10.1016/j.solener.2009.10.003

[12] Joudi, K.A. and Mehdi, S.M. Application of indirect evaporative cooling to variable domestic cooling load, Energy Conversion and Management 41 (17), 1931-51, 2000, DOI https://doi.org/10.1016/S0196-8904(00)00004-2

[13] Kim, M.H., Kim, J.H., Kwon, O.H. and Choi, A.S. Energy conservation potential of an indirect and direct evaporative cooling assisted $100 \%$ outdoor air system, Building Services Engineering Research \& Technology 32 (4), 345-360, 2011, DOI https://doi.org/10.1177/0143624411402637

[14] Wongsuwan, W, Fongsamootre, T. and Cole, M.O.T. Experimental studies on the roof pond house under tropical climatic conditions, KKU Engineering Journal 33 (2), 133-139, 2006 
[15] Spanaki, A. Comparative studies on different type of roof ponds for cooling purposes: Literature review, 2nd PALENC Conference and 28th AIVC Conference on Building Low Energy and Advanced Ventilation Technologies in the 21st Century, Crete Island, Greece, September 1009-1015, 2007

[16] Jain, S.P. and Rao, K.R. Movable roof insulation in hot climates, Building Research and Practice 2 (4), 229-234, 1974, DOI https://doi.org/10.1080/09613217408550323

[17] Zhou, N., Gao, W., Nishida, M, Kitayama, H. and Ojima, T. Field study on the thermal environment of passive cooling system in RC building, Energy and Buildings 36, 1265-1272, 2004,DOI https://doi.org/10.1016/j.enbuild.2003.09.012

[18] Teixeira, C.F.B. and Labaki,C. Evaporative cooling in tropical climate: Case study of Campinas, Brazil, The 23rd Conference on PLEA, Geneva, Switzerland, 6-8 September 2006

[19] Karyono, T.H., Sri, E., Sulistiawan, J.G. and Triswanti, Y. Thermal Comfort Studies in Naturally Ventilated Buildings in Jakarta, Indonesia, Buildings 5, 917-932, 2015, DOI: https://doi.org/10.3390/buildings5030917

[20] Humphrey, M.A. Thermal comfort requirements, climate and energy. In Proceedings of 2nd WREC Conference, Reading, UK, 13-18 September 1992

\section{Author Profile}

Jefrey I. Kindangen is a Professor in Building Sciencesat Sam Ratulangi University. He is a member of the Indonesian Architects Association (IAA), SBSE, ISIAQ and NCEUB. He obtained hisMaster and Ph.D. degrees in Building Design and Urban Engineering from Institut National des Sciences Appliquées (INSA) de Lyon, France. He actively participated in some national and international conferences He has already published some papers in International Scientific Journals: Building and Environment, Building Research and Information, Architectural Science Review and Révue Générale de Thermique.

Linda Tondobala is a lecturer of Architectural Undergraduate and Graduate Program at Sam Ratulangi University. She obtained herMaster and Ph.D. degrees from University of $8^{\text {th }}$ Paris France in Housing and Urban Studies. She is now as the Head of Environmental Study Centre at Sam Ratulangi University.

Markus K. Umboh is now as a lecturer in Mechanical Engineering Department, Sam Ratulangi University. His Master degree graduated from ITB, Indonesia and his Ph.D degree from Toyohashi University in Japan. 